\title{
Towards Protein Functions Prediction: An Inclusive Literature Review of Artificial Intelligent Techniques and Future Research Guidelines
}

\author{
WAFA ALAMEEN ALSANOUSI ${ }^{1}$, NOSIBA YOUSIF AHMED ${ }^{1}$, EMAN MOHAMMED \\ HAMID $^{1}$, K. MURTADA ELBASHIR ${ }^{2}$, JIANXIN WANG ${ }^{3}$, NOMAN KHAN $^{4}$, and * \\ $\mathrm{AFNAN}^{4}$ \\ ${ }^{1}$ Department of Computer Science faculty of mathematical and Computer Science \\ University of Gezira Wad Madani 11123 Sudan \\ ${ }^{2}$ Al-Jouf University College of Information and Computer Sciences \\ ${ }^{3}$ Central South University School of Information Science and Engineering \\ ${ }^{4}$ Visual Analytics for Knowledge Laboratory Department of Software Sejong University \\ Seoul 143-747 South Korea
}

October 26, 2021

\begin{abstract}
Proteins perform critical functions, and their role is closely associated with their composition. Reliable prediction of protein function using computational techniques is becoming necessary because experimental limitations make it difficult to cover the massive rate of discovered proteins and their genetic transformation. This paper surveys the protein functions prediction, briefly discusses the employed literature's workflow and determines if the machine and deep learning techniques have been widely used for similar objectives. Furthermore, the paper discusses the trends of protein datasets and their features and summarises researchers' questions using these datasets. Many features have been identified and extracted, ranging from traditional physicochemical of amino acids and techniques for selecting features and reducing the dimensionality. Distinct from previous study manuscripts, we keep a detailed review of performance evaluation metrics and compare employed protein function prediction methods, thereby concluding the need for efficient, effective, and adaptable protein function prediction methods in real-world scenarios. We describe the machine learning processes and their development from elementary algorithms, such as logistic regression, to more sophisticated methods like conventional and highly developed sequential deep neural networks. The techniques of computing the hyper-parameters that are adopted to improve prediction efficiency have been discussed. Many studies reviewed implemented machine and deep learning approaches for protein function prediction compared with other methods. The critical challenge well noted in protein function prediction is getting relevant information. Then, approaches evaluated and provided future study prospects based on the results drawn from previous studies. This review provides important information as well as future prospects.
\end{abstract}

\section{Hosted file}

Manuscript MS text.docx available at https://authorea.com/users/443133/articles/543186towards-protein-functions-prediction-an-inclusive-literature-review-of-artificialintelligent-techniques-and-future-research-guidelines

\section{Hosted file}

figures.docx available at https://authorea.com/users/443133/articles/543186-towards- 
protein-functions-prediction-an-inclusive-literature-review-of-artificial-intelligenttechniques-and-future-research-guidelines

\section{Hosted file}

MS tables.docx available at https://authorea.com/users/443133/articles/543186-towardsprotein-functions-prediction-an-inclusive-literature-review-of-artificial-intelligenttechniques-and-future-research-guidelines 